\title{
The plight of female infants in India
}

\author{
T. KHOSLA
}

From the Department of Medical Statistics, Welsh National School of Medicine, Cardiff

SUMMARY For most human populations the infant mortality for males is about $20-30 \%$ higher than for females. But in several States of India male infants experience a better survival than females. Many social, religious, and economic factors appear to operate against females throughout India. In the agriculturally prosperous States of Haryana and Punjab the neglect of female infants appears most severe; it is estimated that more than 10000 die of neglect every year. Additional reasons could well be deeply rooted in the turbulent history of north-western India, which has borne the brunt of savage invasions through Afghanistan for several centuries. These areas have not seen peace for the last 1000 years.

Jaya $\mathrm{Rao}^{1}$ has shown that in India males outnumber females at every age except over 70 ; this is at variance with the experience of many other countries. She attributes this to the neglect of females, because females may be expected to survive better than males at every period of life from conception onward. In this paper I examine differential survival by sex in the first year of life in India.

\section{Data and results}

The health statistics of India ${ }^{2}$ provide information for 17 States of India by sex and for rural and urban areas. The infant mortality rates are very high and there is a large variation between States and between rural and urban areas (Table 1). In the rural parts of Bihar, Haryana, ${ }^{*}$ Punjab, ${ }^{*}$ Rajasthan, and Uttar Pradesh, the female infant mortality is higher than that for males. The ratio of male to female infant mortality ranges from 0.80 in Haryana to 1.54 in Himachal Pradesh. Similarly, in five of 16 urban areas the female rate is higher. In only two rural and five urban areas does the ratio of male to female infant mortality exceed $1 \cdot 20$.

INTERNATIONAL VARIATION IN SEX RATIOS The World Health Organisation's annual of statistics for 1977 provides infant mortality rates by sex for 46 countries during 1970-74. Table 2 gives the sex ratios in these countries with broad divisions of high, medium, and low mortality rates. The ratios range from 1.07 in Yugoslavia to 1.45 in Denmark (mean $\pm \mathrm{SD} ; 1 \cdot 26 \pm 0 \cdot 08)$. In no country did the female rate exceed the male rate and in 37 of the 46 countries the ratio was above $1 \cdot 20$.

\footnotetext{
* The Punjab of British India is now divided into three parts: West Punjab in Pakistan and East Punjab and Haryana in India.
}

This female advantage in countries other than India does not appear to be related to race. Barbados, Czechoslovakia, and Switzerland all have a ratio of 1.35 although they have markedly different levels of infant mortality; similarly, Bulgaria, Ireland, Scotland, Thailand, the United States of America, Canada, and Japan have a mortality ratio of $1 \cdot 29$. Despite marked improvements in infant mortality rates during the last 50 years, the ratios of mortality rates have remained virtually static at about 1.30 in the USA, ${ }^{4}$ Scotland, ${ }^{5}$ and Denmark. ${ }^{6}$ In the USA ${ }^{4}$ the mortality ratio is higher for the whites $(1 \cdot 36)$ than for the coloureds $(1 \cdot 25)$.

It would thus appear that for most human populations, irrespective of the level of mortality, a male infant has an increased risk of mortality in the first year of life compared with a female of the order of $20-30 \%$. But this does not prevail in India.

SEX RATIOS IN NEONATAL AND POSTNATAL PERIODS

The sex difference in mortality rates varies appreciably as the newborn infant progresses through the three vulnerable periods of life (early neonatal period 0-6 days; late neonatal period 7-27 days; postnatal period 28-364 days). The World Health Organisation's annual of statistics ${ }^{3}$ documents the breakdown of mortality rates by sex for 24 countries for the years $1950-54,1960-64$, and 1970-74. In each of the 216 comparisons the mortality rates for males appreciably exceed those for females. Figures based on sample registration of births and deaths from certain States of India ${ }^{7}$ show a female advantage up to the neonatal period (Table 3). The advantage appreciably decreases in the postnatal period, and in Assam, Punjab, and Mysore the ratio falls below unity. In the Punjab, excess mortality of females in the postnatal period is high. It 
Table 1 Sex ratios of infant mortality rates for rural and urban areas of 17 States in India, 1970. (Rates per 1000 live births)

\begin{tabular}{|c|c|c|c|c|c|c|c|}
\hline \multirow{2}{*}{\multicolumn{2}{|c|}{ State }} & \multicolumn{3}{|l|}{ Rural } & \multicolumn{3}{|l|}{ Urban } \\
\hline & & Male & Female & $M: F$ & Male & Female & $M: F$ \\
\hline 1. & Andhra Pradesh & 136.6 & $107 \cdot 3$ & $1 \cdot 27$ & $88 \cdot 8$ & $68 \cdot 0$ & $1 \cdot 31$ \\
\hline 2. & Assam & $142 \cdot 3$ & $134 \cdot 3$ & 1.06 & $91 \cdot 1$ & $64 \cdot 1$ & 1.42 \\
\hline 3. & Bihar & $102 \cdot 2$ & $110 \cdot 9$ & $0.92^{*}$ & $67 \cdot 8$ & $85 \cdot 2$ & $0.80^{*}$ \\
\hline 4. & Gujarat & $160 \cdot 8$ & $157 \cdot 5$ & 1.02 & $128 \cdot 2$ & $133 \cdot 8$ & $0.96^{*}$ \\
\hline 5. & Haryana & 73.7 & $92 \cdot 0$ & $0 \cdot 80^{*}$ & $59 \cdot 0$ & $64 \cdot 1$ & $0.92^{*}$ \\
\hline 6. & Himachal Pradesh & $185 \cdot 1$ & $120 \cdot 2$ & $1 \cdot 54$ & $81 \cdot 4$ & 68.6 & $1 \cdot 19$ \\
\hline 7. & Jammu and Kashmir** & $100 \cdot 7$ & $84 \cdot 5$ & $1 \cdot 19$ & - & - & - \\
\hline 8. & Karnataka & $105 \cdot 1$ & 96.9 & $1 \cdot 08$ & $83 \cdot 3$ & $62 \cdot 1$ & $1 \cdot 34$ \\
\hline 9. & Kerala & $59 \cdot 2$ & $52 \cdot 5$ & $1 \cdot 13$ & $41 \cdot 5$ & $37 \cdot 9$ & $1 \cdot 09$ \\
\hline 10. & Madhya Pradesh & $161 \cdot 0$ & $141 \cdot 8$ & $1 \cdot 14$ & $114 \cdot 9$ & 111.4 & $1 \cdot 03$ \\
\hline & Maharashtra & $107 \cdot 5$ & $97 \cdot 1$ & $1 \cdot 11$ & 88.4 & $80 \cdot 0$ & $1 \cdot 10$ \\
\hline 12. & Orissa & $144 \cdot 7$ & $134 \cdot 9$ & 1.08 & $108 \cdot 7$ & 97.4 & $1 \cdot 12$ \\
\hline 13. & Punjab & $98 \cdot 0$ & $110 \cdot 0$ & $0.89^{*}$ & $96 \cdot 8$ & $75 \cdot 3$ & $1 \cdot 29$ \\
\hline 14. & Rajasthan & $144 \cdot 1$ & $153 \cdot 2$ & $0.94^{*}$ & $106 \cdot 8$ & $101 \cdot 9$ & 1.05 \\
\hline 15. & Tamil Nadu & $136 \cdot 1$ & 131.4 & 1.04 & $111 \cdot 8$ & $67 \cdot 2$ & 1.66 \\
\hline 16. & Uttar Pradesh & $158 \cdot 8$ & $172 \cdot 4$ & $0.92^{*}$ & $109 \cdot 5$ & $110 \cdot 9$ & $0.99^{*}$ \\
\hline & West Bengal & 115.4 & $111 \cdot 2$ & 1.04 & $57 \cdot 6$ & $64 \cdot 7$ & $0.81^{*}$ \\
\hline & ALL INDIA & $138 \cdot 1$ & $134 \cdot 5$ & $1 \cdot 03$ & $94 \cdot 2$ & $85 \cdot 1$ & $1 \cdot 11$ \\
\hline \multicolumn{8}{|c|}{ Inter-State } \\
\hline & Mean & 125.4 & $118 \cdot 1$ & 1.07 & 89.7 & $80 \cdot 8$ & $1 \cdot 14$ \\
\hline & SD & $33 \cdot 8$ & $29 \cdot 9$ & 0.17 & $23 \cdot 9$ & $24 \cdot 4$ & 0.22 \\
\hline
\end{tabular}

* Ratios of less than 1.0

**Figures from the urban areas of Jammu and Kashmir are excluded. I suspect a gross printing error.

Table 2 Distribution of male to female infant mortality ratios and countries by levels of infant mortality rates for males (1970-74)

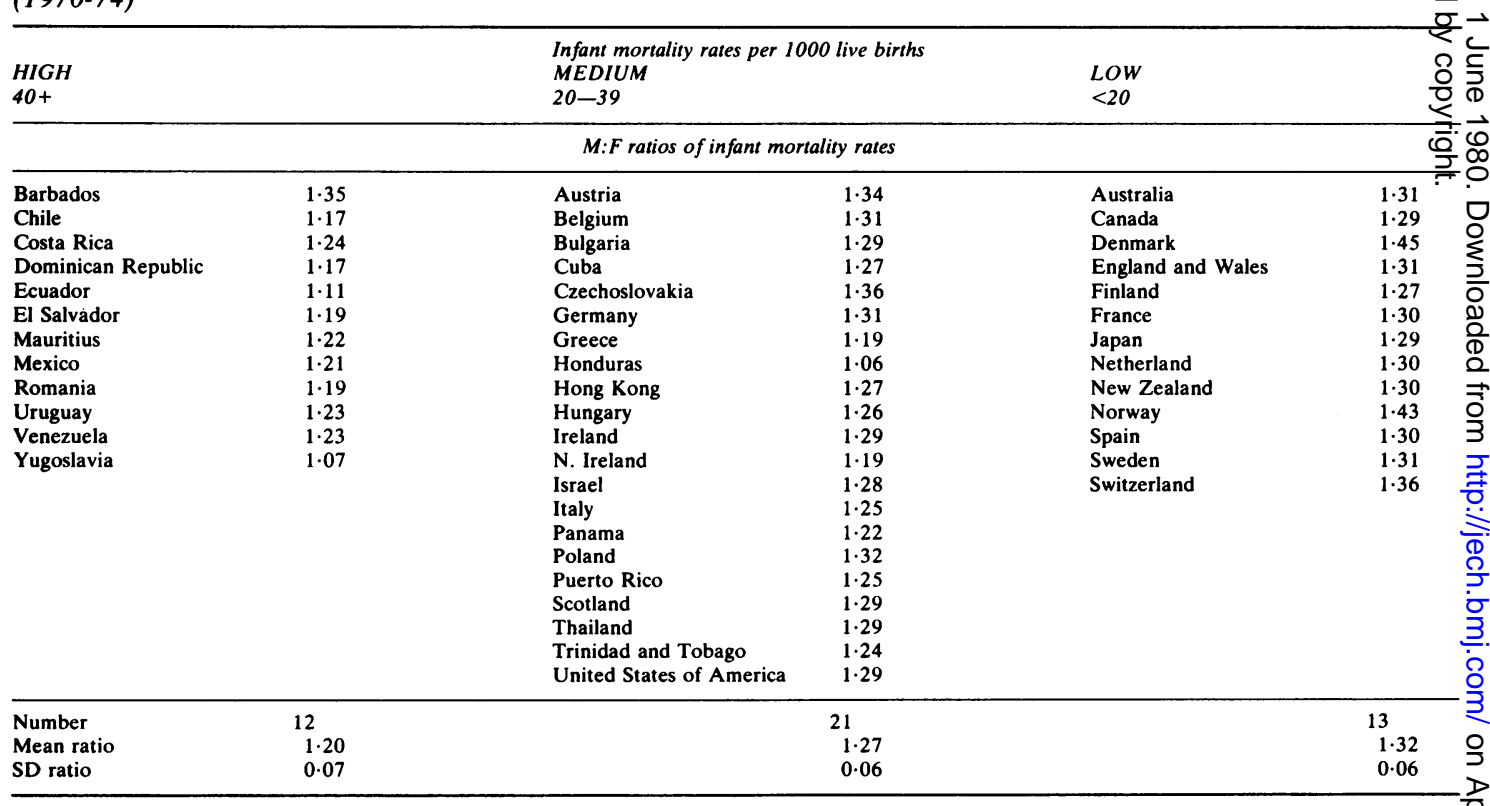

is of interest to note that the excess mortality of males in the perinatal period (ratio 1.57 ) reverses to become an excess mortality of females in the postnatal period (ratio 0.63 ). In general it would seem that during the perinatal and neonatal periods the sex ratio of mortality is not far from the experience observed in other countries, but it is during the postnatal period that the divergence $\mathcal{N}$ begins to arise.

SEX RATIOS IN THE MAJOR DISEASES

The World Health Organisation also presents data on 
Table 3 Sex ratios of mortality rates in neonatal and postnatal periods (Punjab 1969)

\begin{tabular}{lllll}
\hline & Perinatal $^{*}$ & $\begin{array}{l}\text { Neonatal }^{* *} \\
(0-27 \text { days })\end{array}$ & $\begin{array}{l}\text { Postnatal } \\
(28-364\end{array}$ & $\begin{array}{l}\text { Infant } \\
l \text { year }\end{array}$ \\
\hline $\begin{array}{l}\text { Male } \\
\text { Female }\end{array}$ & 34.6 & 36.1 & 34.2 & 70.3 \\
\hline $\begin{array}{l}\text { Ratio } \\
\text { (M/F) }\end{array}$ & 22.1 & 32.9 & 53.8 & 86.7 \\
\hline
\end{tabular}

- Rates per 1000 total births (stillbirths + deaths within a week).

** Rates per 1000 live births.

infant mortality by causes for several countries. ${ }^{3}$ In countries with high infant mortality rates, the major causes are pneumonia, infection of the newborn, ill-defined diseases peculiar to early infancy, and infectious and parasitic diseases. Within the major disease groups the mortality for males is consistently higher than for females. In a country with a low infant mortality rate such as England and Wales, the major causes of mortality are congenital malformation, ill-defined diseases peculiar to early infancy, postnatal asphyxia, and pneumonia, which together account for over $60 \%$ of total infant deaths. Again, within these major groups the male mortality is consistently and appreciably higher than the female mortality.

\section{Discussion}

These consistent trends establish beyond any doubt that nature provides a better survival for females than for males in every ethnic group, in every period of life during the first year, and within every major cause of death in countries of both low and high infant mortality rates.

The finding that in several States of India male infants experience a better survival than females is contrary to the natural law of survival favouring females. In general, social, religious, and economic factors operate against females. Under the social conditions prevalent in several States, parents of girls are subject to heavy financial burdens to provide dowries. In the poor rural areas, where there is little food to go round, possibly relatively less nourishment goes to the female infants. Immunisation rates and medical care may also be lower for them. Jaya $\mathrm{Rao}^{1}$ provides evidence that although protein energy malnutrition is more common among female children, more medical care is sought for boys. Hindu religion requires a son to perform the last rites of parents, and until recently laws of inheritance excluded daughters. The large majority in the poor regions of India lead a life of deprivation; the lot of males is bad and of females worse. Now the population pressure poses a formidable problem.
Some glimmer of hope comes from the most densely populated State of Kerala ${ }^{8}$ which has both the lowest infant mortality and a ratio of male to female mortality in the right direction (Table 1).

The neglect of female infants appears to be most severe in the north-western States of Haryana and Punjab. It is estimated that a low mortality ratio of 0.80 for the rural areas of Haryana, compared with a conservative expected ratio of $1 \cdot 20$ under natural conditions, would account for approximately 30 excess female deaths per 1000 live born females. In rural Punjab a low ratio of 0.89 would account for 28 excess female deaths per 1000 . The reasons for this unnatural loss in Haryana and Punjab are not associated with apathy or poverty because these States are certainly the most prosperous in India; their granaries are said to feed the whole nation. Moreover, their male infant mortality rates are among the lowest in India (Table 1).

Additional historical factors appear to operate against females in these regions. ${ }^{9}$ During the turbulent centuries of wars and invasions, a woman was a liability to her family (see Appendix). In the whole of the north-western area there is a dearth of females; in the Rajput Tonna caste of Gwalior the proportion is as low as $38.4 \%$ of the population. ${ }^{9}$ Among the military castes the birth of a female child does not appear to be a happy occasion. According to hearsay, female infanticide was practised 50 years ago in some regions and today the neglect of female infants is a possibility that cannot be ruled out.

The plight of these infants in Haryana and Punjab needs alleviating at national level; it is estimated that more than 10000 aged under 12 months die of neglect each year.

I thank Professor H. Campbell and Dr. R. G. Newcombe for helpful comments.

Reprints from Dr. T. Khosla, Department of Medical Statistics, Welsh National School of Medicine, Heath Park, Cardiff CF4 4XN.

\section{Appendix}

Turbulent history of North-western India ${ }^{9}$

Rajasthan and Punjab bore the brunt of many invasions between 1018 and 1739 through Afghanistan. For several centuries in these turbulent parts of India a woman was a liability to her family. It was difficult to protect her honour. Her life ceased when her protector, the husband, died. It was common for Rajput women to immolate themselves 
according to the terrible rite of suttee after the deaths of their husbands in battle or otherwise. Later these practices spread to other parts of India, and holocausts of such victims are recorded in the kingdom of South India. Suttee was carried out wholesale; as many as 3000 were said to have been burnt on one occasion.

The Rajput military castes are mainly in the Punjab and Rajasthan, and other important groups in these areas are Sikhs. It appears that the Gurkhas are also descendants of Rajputs who fled from Chitor after its capture by Mohammedans in 1303; the Rajputs settled in the town of Gurkha and ultimately made themselves masters of Nepal.

After the fall of the Mogul Empire in India, the Sikhs ruled Punjab until its annexation by the British after two wars in 1849. After Independence, the old bitterness between Sikh and Muslim was fanned by the award of the boundary commission in 1947 dividing the Punjab in two (Western Punjab in Pakistan and Eastern Punjab in India). The division resulted in the forced migration of millions between the two Punjabs. More recently two Indo-Pakistan wars were fought on the borders of divided Punjab. These north-western areas of India have endured more than 1000 years of wars.

\section{References}

${ }^{1}$ Jaya Rao KS. Attitudes to women and nutrition programmes in India. Lancet 1979; 2: 1357-8.

${ }^{2}$ Ministry of Health and Family Planning. Health Statistics of India 1971-75. New Delhi: Controller of Publications Delhi 110006, 1977.

${ }^{3}$ World Health Organisation. World Health Statistics $\stackrel{T}{\mathbb{D}}$ Annual, Volume I. Vital Statistics and Causes of Death. Geneva: WHO, 1977.

${ }^{4}$ National Center for Health Statistics. Infant and Perinata Mortality in the United States. Public Health Services Publication Series 3 No. 4. Washington DC: USO Department of Health, Education and Welfare, 1965 . ${ }^{5}$ Registrar General for Scotland. Mortality Statistics Part I.

${ }^{6}$ National Center for Health Statistics. Infant and Perinatal ${ }_{\overparen{Q}}$ Mortality in Denmark. Public Health Service Publication Series 3 No. 9. Washington DC: USC Department of Health, Education and Welfare, 1967.

${ }^{7}$ Ministry of Home Affairs. Sample Registration of Births. and Deaths in India 1969-70. New Delhi: Vital Statistics $\overrightarrow{-}$ Division, Office of Registrar General of India 1972. 1972.

${ }^{8}$ Khosla T. Year of the Child: look at Kerala. Lancet $1979 . \mathbb{8}$ 2: 1133 .

${ }^{9}$ Chambers Encyclopaedia. Chapters on Indian history Nepal, and Sikhs. London: Chambers, 1970; volumín VII: 456-71; volume IX: 741-3; volume XII: 550- 